\title{
Perception of micro small and medium enterprise entrepreneurs on banking services
}

\author{
M. Suryakumar ${ }^{1}$, T. Thirunavukkarasu ${ }^{2, *}$ \\ ${ }^{\mathbf{1}}$ Assistant Professor, ${ }^{2}$ Research Scholar, Periyar Institute of Management Studies (PRIMS), Periyar University, Salem, \\ Tamil Nadu, India
}

*Corresponding Author:

Email: thiruna.arasu90@gmail.com

\begin{abstract}
The breakdown rate of current Micro, Small and Medium enterprises (MSMEs) is very high. Access to finance is one amongst the predominant constraints to the endurance of latest MSMEs. The objective of the research is to seem to be at the acuity of MSME entrepreneurs on historic and revolutionary funding selections or funding serves attainable in banks. The research analyzed about the standard sources of equity and debt like business angels, venture capitalists, trade credit and a range of government schemes. There's the necessity to produce restrictive a impression that may additionally support to the development of MSMEs in India.
\end{abstract}

Keyword: MSMEs, Banking services, Financing, Equity, Schemes.

\section{Introduction}

Micro, Small and Medium Enterprises (MSMEs) have been believe as the engine of monetary growth and for encouraging equitable growth. MSMEs represent over $90 \%$ of business in most of the economies are credited with producing the best of employment growth and account for a most important share of industrial manufacturing and exports. In India too, the MSMEs plays a pivotal role in the ordinary industrial economic system of the country. MSMEs in India account for greater than $80 \%$ of the total number of industrial enterprises and produce over 8000 valueadded products. It is estimated that in terms of value, this sector accounts for $45 \%$ of the manufacturing output and $40 \%$ of the whole export of the country and employs over 6 crore people.

Customer Perception: Dash et al. 2009 moreover measure up to the perceptions of consumers regarding the standard of banks' services in Canada and India. It's in addition obvious that not any of previous studies set aside the banks' customers into sexual category, age, education, profession and geological locations (Social Category and districts/regions). They exclusively checked out the ultimate observation of consumers even though a few of research that centered on only one country like Lopez et al (2007), Galloway and Blanchard (1996), and Lewis (1994), Caruana (2002) classified the banks' customers into profession, age, race and education severally, none of them used of these variables at regular time or classify them dependable with geographical area.

Satisfaction might be a critical anxiety for each customer and organizations as well as banks. Customer fulfillment can be a personal commencement and thus not easy to find out, (European Institute of Public Administration, 2008). It depends on a countless of things and be different from one person to another person similarly as one product to another product. A number of the most ideas of satisfaction within the literature embody worth, quality and satisfaction. Worth per Zeithaml (1988) is that the significance passionate up to services supported their practice and then the amount compensated in exchange. Worth on the contradictory hand, is that the gathering of the desire and wants of clients, Fecikova (2004) and (ISO 2005) assess the happiness is that the convention of requirements or wants of consumers. From the preceding, it will be seen that everyone these ideas are measure a similar and used interchangeably.

\section{Review of Literature}

Prof. Mishu Tripathi, Mr. Saurabh Tripathi and Mr. Rikin Dedhia (2016) a major impediment to the boom of the imperative Indian micro, small and medium organizations (MSME) area is its lack of ample access to finance. This paper examines the fundamental troubles in the financing of MSMEs in the Indian context, such as the facts asymmetry going through banks and the efficacy of measures such as savings drift for MSMEs; whether transaction lending would be sufficient to address the statistics problems or would lending have to be based on a relationship with the MSME, using each 'hard' and 'soft' information; and whether the dimension and origin of the bank have an effect on the availability of deposit to MSMEs. Some factors are multiplied in the paper, such as the function and importance of the deposit flow to MSME area for the economic boom and improvement and the function that banks can play in growing the MSME area in India.

Angayarkanni (2011) in her study on problems of women entrepreneurs in India, exposed that evenly in education is the key to gather dissimilar requirements for a subculture of peace. Women proceed to face boundaries to financial empowerment and entrepreneurship, these difficulties include unfairness in education, training, recruiting, and right to use credit, 
the right to own and come into appropriately, lower tiers of pay, encouragement for equal work and greater domestic responsibilities for women.

Anamalai S and Buvaneshwari. P (2010) studied that the typical overall performance of private banks during the year 2008-09 was better than the previous year. They analyzed the productivity parameter of the bank like deposit per branch, advance per branch, business per branch, deposit per employee and advance per employee, advance per employee should a considerable in important over the year.

\section{Objectives of the Study}

1. To find whether MSME entrepreneurs are Aware, Utilized and Satisfied towards banking services.

2. Find out the MSME entrepreneurs Preference towards banking services

\section{Methodology of the Study}

Research is defined as progress from the known to the unknown. It is an effort to find out something. According to Clifford Woody "Research comprise defining and redefining problems formulating hypothesis or suggested solutions, collecting organizing and evaluating data making, deduction \& research conclusions and at remaining cautiously testing the conclusion to decide whether or not they healthy the components hypothesis.

\section{Research Design}

The study is concerned with the entrepreneurs in Tiruppur district. The study describes the entrepreneurs' awareness and satisfaction towards banking services and to analyze their opinion. Research design is a plan of action that guides the entire research in our study descriptive research design has been adopted.

\section{Sampling Design and Method}

Tiruppur district is one of the largest industrial districts in the state of Tamil Nadu. The district consists of a large number of textile mills, engineering industries particularly of micro, small and medium enterprises and agro based industries. The presence of a vast number of MSMEs in the district reveals the entrepreneurial talent of the population of this district.

The researcher has taken two hundred and thirty units as sample units for the present study and the data were collected from the proprietors of these units. Initially, the researcher obtained the list of total MSMEs in Tiruppur district from District industries Centre (DIC), the information relating to the research were obtained from the proprietors of these two hundred and thirty units. Probability sampling was applied to select the sample. Simple random sampling has been used for the gathering of primary data from the respondents

\section{Framework of Analysis}

After data collection, the researcher analyzed statistically. Frequencies and percentage distributions were used to analyze data on the respondent's profile, chi square, ANOVA and fried man rank correlation were used for data analysis.

Table 1: Fried Man rank correlation regarding preference based on entrepreneurs in banking services (SA- strongly Agree, A-Agree N- Neutral, DA- Disagree, SDA- Strongly Disagree)

\begin{tabular}{|l|c|c|c|c|c|c|c|}
\hline \multicolumn{1}{|c|}{ Preference } & S A & $\mathbf{A}$ & $\mathbf{N}$ & $\mathbf{D A}$ & SDA & Rank value & Rank \\
\hline Easy OD facility & $48(20.90)$ & $\begin{array}{c}87 \\
(37.80)\end{array}$ & $\begin{array}{c}32 \\
(13.90)\end{array}$ & $\begin{array}{c}45 \\
(19.60)\end{array}$ & $\begin{array}{c}18 \\
(7.80)\end{array}$ & 8.41 & 4 \\
\hline $\begin{array}{l}\text { Offering Financial } \\
\text { consultancy }\end{array}$ & $\begin{array}{c}53 \\
(23.00)\end{array}$ & $\begin{array}{c}56 \\
(24.30)\end{array}$ & $\begin{array}{c}26 \\
(11.30)\end{array}$ & $\begin{array}{c}52 \\
(22.60)\end{array}$ & $\begin{array}{c}43 \\
(18.70)\end{array}$ & 6.27 & 10 \\
\hline $\begin{array}{l}\text { For converting foreign } \\
\text { currency }\end{array}$ & $\begin{array}{c}52 \\
(22.60)\end{array}$ & $\begin{array}{c}51 \\
(22.20)\end{array}$ & $\begin{array}{c}34 \\
(14.80)\end{array}$ & $\begin{array}{c}28 \\
(12.20)\end{array}$ & $\begin{array}{c}65 \\
(28.30)\end{array}$ & 6.72 & 11 \\
\hline Low processing fees & $\begin{array}{c}67 \\
(29.10)\end{array}$ & $\begin{array}{c}20 \\
(8.70)\end{array}$ & $\begin{array}{c}33 \\
(14.30)\end{array}$ & $\begin{array}{c}46 \\
(20.00)\end{array}$ & $\begin{array}{c}64 \\
(27.80)\end{array}$ & 6.98 & 8 \\
\hline Low rate of interest & $\begin{array}{c}57 \\
(24.80)\end{array}$ & $\begin{array}{c}84 \\
(36.50)\end{array}$ & $\begin{array}{c}34 \\
(14.80)\end{array}$ & $\begin{array}{c}37 \\
(16.10)\end{array}$ & $\begin{array}{c}18 \\
(7.80)\end{array}$ & 8.42 & 3 \\
\hline Quick disbursal of loan & $\begin{array}{c}69 \\
(30.00)\end{array}$ & $\begin{array}{c}69 \\
(30.00)\end{array}$ & $\begin{array}{c}34 \\
(14.80)\end{array}$ & $\begin{array}{c}33 \\
(14.30)\end{array}$ & $\begin{array}{c}22 \\
(9.60)\end{array}$ & 8.06 & 6 \\
\hline Proximity & $\begin{array}{c}66 \\
(28.70)\end{array}$ & $\begin{array}{c}71 \\
(30.90)\end{array}$ & $\begin{array}{c}21 \\
(9.10)\end{array}$ & $\begin{array}{c}39 \\
(17.00)\end{array}$ & $\begin{array}{c}33 \\
(14.30)\end{array}$ & 7.89 & 7 \\
\hline $\begin{array}{l}\text { Wide variety of loan } \\
\text { schemes }\end{array}$ & 82 \\
\hline Less insistence of \\
security
\end{tabular}


Interpretation: Out of 230 respondents 78(33.90) respondents strongly agree that they preference in availing subsidy benefit from banks, and their mean rank is $9.10,82(35.70)$ respondents strongly agree that they preference is wide variety of loan schemes provided by banks, and their mean rank is 8.78 .57
(24.80) respondents strongly agree that they preference for low interest, and their mean rank is 8.42. Likewise all the factors are ranked.

Chi-Square (184.822) the entrepreneur's preference and banking services are differs.

Table 2: Chi-square test on area of residence and level of awareness H0: association between area of residents and level of awareness index

\begin{tabular}{|c|c|c|c|c|c|}
\hline \multirow[t]{2}{*}{ Area of Residence } & \multicolumn{4}{|c|}{ Level of Awareness } & \multirow[t]{2}{*}{ Total } \\
\hline & \multicolumn{2}{|c|}{ Low } & Moderate & High & \\
\hline \multirow[t]{2}{*}{ Urban } & No. & 19 & 88 & 23 & 130 \\
\hline & $\%$ & $(14.60)$ & $(67.70)$ & $(17.70)$ & $(100.00)$ \\
\hline \multirow[t]{2}{*}{ Semi-urban } & No. & 16 & 47 & 10 & 73 \\
\hline & $\%$ & $(21.90)$ & $(64.40)$ & $(13.70)$ & $(100.00)$ \\
\hline \multirow[t]{2}{*}{ Rural } & No. & 04 & 21 & 02 & 27 \\
\hline & $\%$ & $(14.80)$ & $(77.80)$ & $(7.40)$ & $(100.00)$ \\
\hline Total & \multicolumn{2}{|r|}{39} & 156 & 35 & 230 \\
\hline
\end{tabular}

Df: 4, Table Value: 5\%: 9.487, Calculated $\chi^{2}$ Value: 6.791

Out of 230 entrepreneurs, 130 (56.52) reside in urban area. Of which, 19 (14.60) respondents are with low level of awareness, 88 (67.70) respondents are with moderate level of awareness and the rest 23 (17.70) are with high level of banking awareness. Seventy Three (31.74) entrepreneurs reside in semi urban area. Of which, 16 (21.90) MSME industrialist are with low level of banking awareness, 47 (64.40) respondents are with moderate level of awareness and the rest 10 (13.70) respondents are with high level of banking awareness. And twenty Seven (11.74) respondents reside in rural area. Of which, 04 (14.80) entrepreneurs are with low level of awareness, 21 (77.80) are with moderate level of awareness and the rest 02 (7.40) are with high level of banking awareness.

The percentage of entrepreneurs with high level of awareness is found high amongst entrepreneurs residing in urban location. As the calculated chi-square value is less than the table value at five percent significant level, there does not exists any significant association between area of residence and level of banking awareness. Hence, the null hypothesis is accepted.

In this finding is related to the findings of Gayathiri Balakrishnan (2010) has found amongst that present does not exists any significant association between area of resident and level of awareness. Urban area has been suitable for residing and more source available for easily running the business so most of the entrepreneurs are staying, running a business in urban areas. And they have a high level of awareness because more number of banks and banking institutions available in urban area. In economic development urban area contribution is more. Hence banks more focusing and introduce a new product, new facilities for urban area entrepreneurs.

Table 3: ANOVA- Area of residence and level of awareness index

\begin{tabular}{|c|c|c|c|c|c|c|}
\hline $\begin{array}{c}\text { Area of } \\
\text { Residence }\end{array}$ & \multicolumn{2}{|c|}{ Total } & $\begin{array}{c}\text { Awareness } \\
\text { Index }\end{array}$ & $\begin{array}{c}\text { Above } \\
\text { Average }\end{array}$ & $\begin{array}{c}\text { Below } \\
\text { Average }\end{array}$ & Range \\
\hline \multirow{2}{*}{ Urban } & No. & 130 & 70.68 & 66 & 64 & $52.38-83.33$ \\
\hline & $\%$ & $(56.52)$ & & $(50.77)$ & $(49.23)$ & \\
\hline \multirow{2}{*}{ Semi-urban } & No. & 73 & 69.05 & 43 & 30 & $54.76-83.33$ \\
\hline & $\%$ & (31.74) & & $(58.90)$ & (41.10) & \\
\hline \multirow{2}{*}{ Rural } & No. & 27 & 70.62 & 14 & 13 & $59.52-80.95$ \\
\hline & $\%$ & (11.74) & & $(51.85)$ & $(48.15)$ & \\
\hline Total & \multicolumn{2}{|c|}{230} & 70.17 & 122 & 108 & $52.38-83.33$ \\
\hline
\end{tabular}

d.f.: $v_{1} 2, v_{2} 227$, Table Value: 5\%: 3.035, Calculated F Value: 1.550

Out of 230 entrepreneurs 130 (56.52) entrepreneurs reside in urban area. Their awareness index is 70.68 . Of which, 64 (49.33) entrepreneurs awareness index are below average and 66 (50.77) entrepreneurs awareness index are above average. Their awareness index ranges from 52.38 and 83.33. Seventy three (31.74) entrepreneurs reside in semi-urban area. Their awareness index is 69.05. Of which, 30 (41.10) entrepreneurs awareness index are below average and 43 (58.90) entrepreneurs awareness index are above average. Their awareness index ranges from 54.76 to 83.33. And twenty seven (11.74) entrepreneurs reside in rural area. Their awareness index is 70.72 . Of which, 13 (48.15) entrepreneurs awareness index are below 
average and 14 (51.85) entrepreneurs awareness index are above average. Their awareness index ranges from 59.52 to 80.95 .

Mean awareness index is found high among MSME an entrepreneur, who resides in urban area. Mean awareness index is found low among entrepreneurs, who reside in semi urban area. Hence, it is inferred that entrepreneurs reside in urban area have high level of awareness. As calculated F value is less than the table value at five per cent level, there does not exists any significant mean difference among entrepreneurs classified on the basis of area of residence.

Table 4: MSME entrepreneurs level of awareness on banking services and schemes

\begin{tabular}{|c|c|c|c|c|}
\hline \multirow{2}{*}{ Particulars } & \multicolumn{4}{|c|}{ Level of Awareness } \\
\hline & Mean & Std. Deviation & Interpretation & Rank \\
\hline OD & 2.45 & .642 & High & 2 \\
\hline foreign exchange facility & 1.88 & .686 & Low & 18 \\
\hline letter of credit & 1.33 & .493 & Low & 19 \\
\hline bill of exchange & 1.17 & .473 & Low & 22 \\
\hline Pre-shipment & 1.14 & .403 & Low & 24 \\
\hline Post-shipment & 1.14 & .403 & Low & 25 \\
\hline Equity Financing & 1 & 0.000 & Low & 26 \\
\hline Cash Credit & 2.19 & .662 & High & 5 \\
\hline Advance against bills & 2.14 & .569 & High & 7 \\
\hline Receivable finance & 2.13 & .597 & High & 8 \\
\hline CGTMSE & 3 & 0.000 & High & 1 \\
\hline SME SMARTSCORE & 1.97 & .643 & Low & 13 \\
\hline SME SMILE & 1.94 & .633 & Low & 14 \\
\hline Open term loan & 2.4 & .586 & High & 3 \\
\hline SME Cons & 1.15 & .411 & Low & 23 \\
\hline SME Credit plus & 2.07 & .655 & High & 10 \\
\hline stand by line of credit & 2.12 & .608 & High & 9 \\
\hline SME Collateral free loan & 1.92 & .692 & Low & 16 \\
\hline PMEGP & 2.33 & .652 & High & 4 \\
\hline KADHI & 1.89 & .723 & Low & 17 \\
\hline CLCS & 2.04 & .618 & High & 11 \\
\hline MPS & 1.94 & .617 & Low & 15 \\
\hline IDP & 1.59 & .605 & Low & 20 \\
\hline UIEGP & 2.03 & .627 & High & 12 \\
\hline MUTHRA & 2.16 & .631 & High & 6 \\
\hline Stand up India & 1.61 & .680 & Low & 19 \\
\hline
\end{tabular}

Interpretation: There are twenty six variables used on which the MSME entrepreneurs awareness and utilization of banking service is measured. That is shown in the above table, from the assessment of the score notable that, overdraft facility, cash credit, advance against bills, Receivable finance, CGTMSE, open term loan, SME Credit plus, Stand by line of credit, PMEGP, CLCS,UIEGP and MUTHRA factors are having the highest mean score of awareness level. Hence the above mentioned factors are highly aware by MSME entrepreneurs. Many of the factors having low level of mean value, hence banks have to concentrate more on these service promotions.

Table 5: MSME entrepreneurs level of utilization on banking services and schemes

\begin{tabular}{|l|c|c|c|c|}
\hline \multirow{2}{*}{\multicolumn{1}{c|}{ Particulars }} & \multicolumn{4}{c|}{ Utilization } \\
\cline { 2 - 5 } & Mean & Std. Deviation & Interpretation & Rank \\
\hline OD & 2.33 & .682 & High & 1 \\
\hline foreign exchange facility & 1.04 & .650 & Low & 22 \\
\hline letter of credit & 1.08 & .613 & Low & 18 \\
\hline bill of exchange & 1.07 & .674 & Low & 19 \\
\hline Preshipment & 0.85 & .716 & Low & 26 \\
\hline Postshipment & 1.01 & .677 & Low & 23 \\
\hline Equity Financing & 0.97 & .674 & Low & 24 \\
\hline
\end{tabular}




\begin{tabular}{|l|c|c|c|c|}
\hline Cash Credit & 2.12 & .613 & High & 4 \\
\hline Advance against bills & 2.14 & .697 & High & 2 \\
\hline Receivable finance & 2.13 & .646 & High & 3 \\
\hline CGTMSE & 2.06 & .679 & High & 5 \\
\hline SME SMARTSCORE & 1.95 & .702 & Low & 10 \\
\hline SME SMILE & 1.88 & .686 & Low & 14 \\
\hline Open term loan & 2.03 & .658 & High & 6 \\
\hline SME Cons & 1.00 & .667 & Low & 25 \\
\hline SME Credit plus & 1.91 & .653 & low & 13 \\
\hline stand by line of credit & 1.94 & .664 & low & 12 \\
\hline SME Collateral free loan & 1.67 & .674 & low & 15 \\
\hline PMEGP & 2.01 & .659 & High & 8 \\
\hline KADHI & 1.06 & .633 & low & 21 \\
\hline CLCS & 2.01 & .659 & High & 9 \\
\hline MPS & 1.57 & .643 & low & 16 \\
\hline IDP & 1.36 & .680 & low & 17 \\
\hline UIEGP & 1.95 & .672 & low & 11 \\
\hline MUTHRA & 2.03 & .658 & High & 7 \\
\hline Stand up India & 1.07 & .685 & low & 20 \\
\hline
\end{tabular}

Interpretations: The above table is shown, from the assessment of the mean score notable that, Overdraft Facility, Cash Credit, Advance against bills, Receivable finance, CGTMSE, Open term loan, SME Credit plus, Stand by line of credit, PMEGP, CLCS,UIEGP and
MUTHRA factors are having the highest mean score of awareness level. Hence the above mentioned factors are highly aware by MSME entrepreneurs. Many of the factors having low level of mean value, hence banks have to concentrate more on these service promotions.

\section{Chart 1: Level of MSME entreprenurs awareness and utilization of banking services}

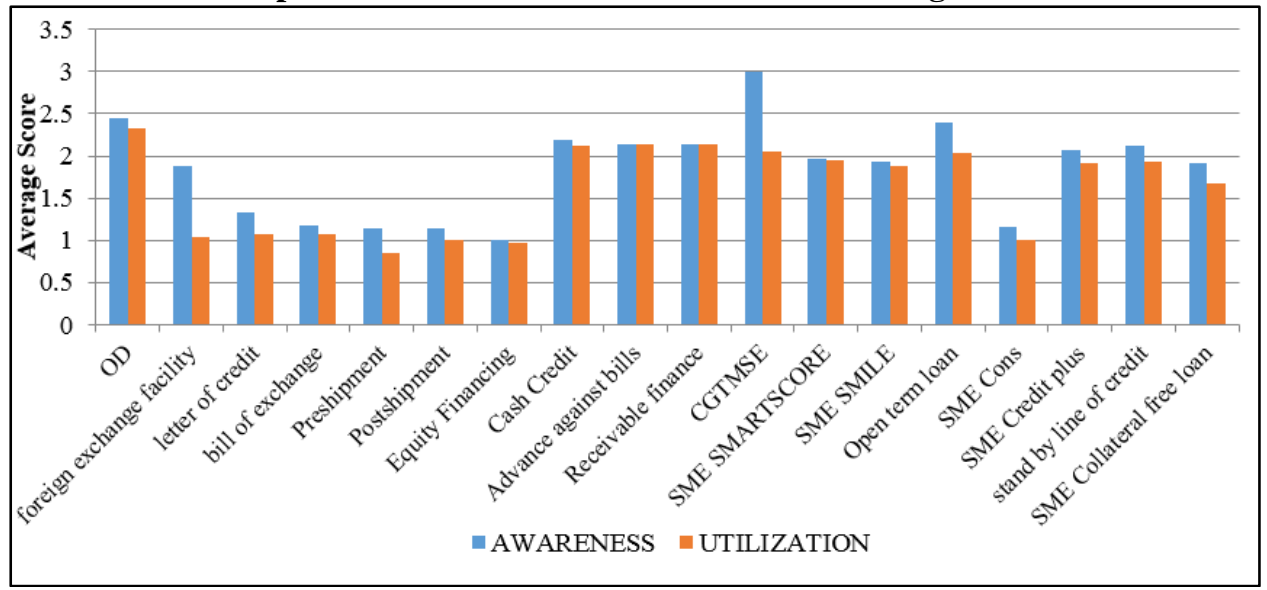

Chart 2: Level of MSME entreprenurs awareness and utilization of various schemes

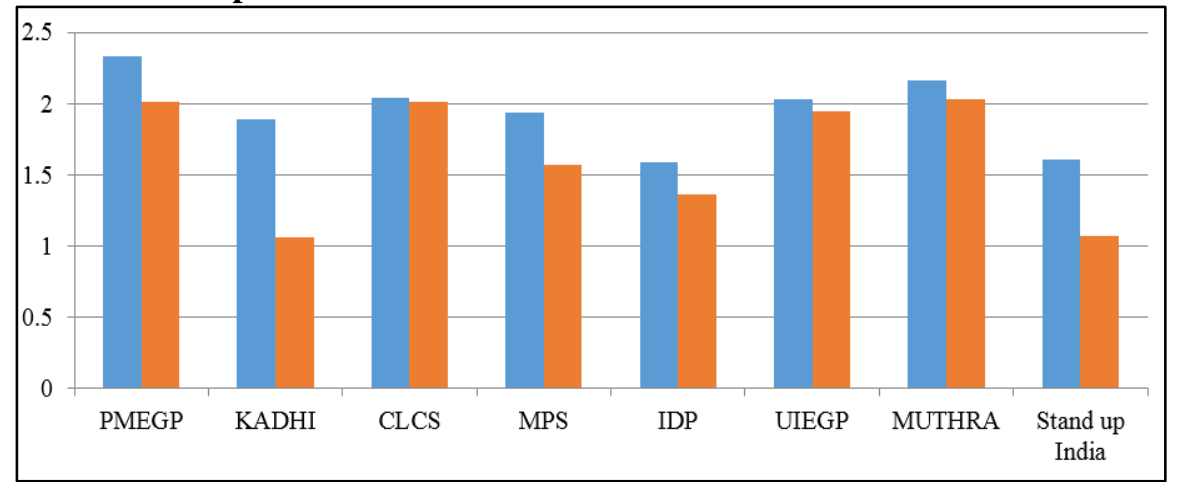


Above chart shows the awareness level and utilization level, mean values of both awareness and utilization is using to compute this chart. It shows the comparison of awareness and utilization, even all the factors awareness values is higher than the utilization values because there are so many rules and regulations contributed while utilizing the banking services. Consumer expectations are formed by the external connections of an organization, the nature of the gaps connected with marketing, design and delivery of services.

\section{Recommendations}

This section undertakes the suggestions acquired from the study findings. These recommendations area unit impart basing on the analysis objectives

According to the research findings, the researcher would recommend bank to improve the standard of its service so as to enlarge the attitude of customer satisfaction by rising employees ability to handle customers analysis and customers problem in steadiness manner, and additionally bank ought to concentrate additional in fast disbursal of loan really it'll take longer to disbursed. It becomes clear that industrial banks ought to build efforts to enhance all the variables that have a bearing on satisfaction of small and medium-sized enterprises with banks business-oriented services, as business-oriented services are thought-to about be a really necessary determinant that influences an overall customers' satisfaction with the bank and therefore the money results of the bank itself.

In credit service, certain percent of the customer are still being of the opinion that the bankers are less cooperative in processing the loan. This can be further reduced by speeding up the process with the help of electronic mode of scrutinizing the application form. The tracking of loan application form is another major issue faced by the customers. Hence the banks can apply business process management in the type of centralized loan process which helps the banks to reduce the time to process the loan request and tracking the status of each loan application. The status of loan processing should be informal to the customers at regular intervals either through e-mail or online banking portals and should be made as mandatory. Complexity in the documentation procedure should also be eased to enhance the customers' satisfaction on the credit service.

The procedures of loan sanctioning loan should be simplified and loan application should be appraised as early as possible.

\section{Conclusion}

The study mainly focuses on MSME Entrepreneurs Awareness, Satisfaction, and Preference towards banking services. In terms of awareness level on banking products and technological based banking services in Tiruppur district.
A study on entrepreneur's satisfaction level at banking services reveals that customers are satisfied towards promptness of services, overall efficiency of the bank and friendliness and courtesy of the managers. Some areas the utilization level is very poor. Suitable suggestions are also provided to increase the satisfaction and utilization level in those areas.

Hence, the findings and suggestions provided by the research will help to enlarge the satisfaction level of customers. As well as to get better the quality of the product and services provided by the bankers.

\section{Scope for Further Research}

Based on the results made by the researcher to recognize the research gap and completing the research, the researcher has identified the following scope for further research which is follows.

1. A comparative study on individual customers and corporate customers with observe to the acuity and level of satisfaction on modern services of the commercial banks

2. Problems and Prospects of mobile banking services in India.

3. A study on the causes of non adoption of modern banking services.

4. A comparative study on modern banking services a many location and foreign banks.

\section{References}

1. Kothari C.R. Research Methodology Methods and Techniques, Second Edition, New Age International (P) Ltd, 2004.

2. Kotler. P, "Marketing Management", $11^{\text {th }}$ Edition, Pearson Education, New Delhi, 2002.

3. Richard I. Levin and David S. Rubin, "Statistics for Management" $7^{\text {th }}$ Edition, Pearson Education, 2002.

4. Subbarao. P.S, "Entrepreneurship and Small Business Management". Discovery publishing House, New Delhi, 2001.

5. Mishu Tripathi, Saurabh Tripathi, Rikin Dedhia. (2016) Challenges Faced by Micro, Small and Medium Enterprise (MSME) sector in India. International Journal of Science and Technology and Management. 2016;5(3):69-77.

6. Anamalai S, Buvaneshwari. P. Studied that the Overall Performance of Private sector Banks. Facts for you. 2011;30(10):22-28.

7. Angayarkanni, Problems of Women Entrepreneurs in India. Southern Economist, 2010;48(19).

8. Gayathribalakrishnan .R. Awareness level of Customer about Banking Service offered by both the Private sector and Public sector Banks. Southern Economist. 2010;19:13-16.

9. http://www.tradeindia.com/newsletters/special_report/tips _13_feb_2007.html

10. http://smesummit.smechamberofindia.com/Preamble.aspx

11. www.ediindia.com

12. www.nisc.com

13. www.ediindia.ac.in 